http://journal.uinsgd.ac.id/index.php/biodjati

\title{
MORPHOLOGY CHARACTERIZATION OF RHOPALOCERA IN TWO AREAS OF RESORT BUKIT TIGA PULUH NATIONAL PARK RIAU PROVINCE
}

\author{
Ennie Chahyadi ${ }^{1 *}$, Mayta Novaliza Isda ${ }^{2}$, Appriliya Destiyana ${ }^{3}$, Fitmawati ${ }^{4}$, \\ Desita Salbiah $^{5}$
}

Received : August 22, 2019

Accepted : May 07, 2020

DOI: 10.15575/biodjati.v5i1.5743

${ }^{1,2,3,4}$ Department of Biology Faculty of Mathematic and Natural Sciences Universitas Riau, Jl. Bina Widya Simpang Baru, Pekanbaru Riau 28293, Telp/Fax (0761) 63273/63279

${ }^{5}$ Department Agrotechnology Faculty of Agriculture, Universitas Riau

Jl. Bina Widya Simpang Baru Pekanbaru Riau 28293, Telp/Fax (0761) $63273 / 63279$

e-mail:

*1ennie.chahyadi@gmail.com

maytaisda@yahoo.com

3wyyana@yahoo.com

4fitmawati2008@yahoo.com

ssdesita@yahoo.com

*Corresponding author

Abstract. Bukit Tiga Puluh National park (TNBT) of Riau Province is a nature conservation area with a high diversity of fauna, one of which is the butterfly. Butterfly species diversity is influenced by the vegetation in their habitat. The TNBT utilization zone has a habitat type with varied vegetation. There is no information about the species of butterflies in the area. This study aimed to identify morphological character of butterflies and vegetation based on morphological characters. The method used was exploration. The catching area of the butterfly was the Granite waterfall and the Bukit Lancang path of TNBT utilization zone. Samples made as insectarium and herbarium. The identification of butterfly characters consisted of the head, thorax, abdomen, legs and wings. There were a number of different types of butterflies and plants between the Granite waterfall area (22 and 28 species) and the Bukit Lancang paths (5 and 9 species). The type of butterfly was dominated by the family Nymphalidae. This is due to the amount of vegetation and environmental conditions that are more favorable in the granite waterfall area. The key determinants of butterfly species are the characters of the wing. The results of this study can contribute to maintaining the TNBT butterflies in Riau Province and also as database information of butterflies species in Indonesia.

Keywords: butterflies, morphology, Rhopalocera, TNBT, vegetation

\section{Citation}

Chahyadi, E., Isda, M. N., Destiyana, A., Fitmawati \& Salbiah, D. (2020). Morphology Characterization of Rhopalocera in Two Areas of Resort Bukit Tiga Puluh National Park Riau Province. Jurnal Biodjati, 5(1), 125-137.

\section{INTRODUCTION}

Suborder Rhopalocera is known as a group of insects from the order of Lepidoptera which are active during the day. These insects, called butterflies, have beautiful and attractive colour morphological characters (Scoble, 1995; Campbel et al., 2000). The presence of butterflies in an area and tourist attraction can be a charm for tourists and entomolo- gists. In addition to its interesting morphology, butterflies also have an important role in the ecosystem. Most species of butterflies act as pollinators, can also be used as a bioindicator of an environment. The existence, the survival rate and diversity of butterfly species are closely related to food availability, in this case the vegetation in their habitat (Subahar \& Yuliana, 2012; Peggie, 2014; Rinanda et al., 2016). Furthermore, environmental factors 


\section{JURNAL BIDDJATI}

http://journal.uinsgd.ac.id/index.php/biodjati

such as air temperature and lighting also affect the life of a butterfly (Putri, 2014). So the role of butterflies is important in nature and is beneficial for humans from the aspects of ecology, aesthetics, economics, culture and research (Raja, 2012).

The importance of knowing the types of butterflies in an area is one of the inventory efforts that can be used as a first step for the conservation and management of butterflies in area. Bukit Tiga Puluh National Park, also known as TNBT is one of the important nature conservation in Riau Province. It is located in Indragiri Hulu and Hilir in Riau Province, and so Tanjung Jabung Barat and Tebo Regencies, Jambi Province. TNBT is lowland tropical forest ecosystem that consists of three main zones, one of them is the utilization zone. In this zone, there are several areas including the Granit Waterfall and the Bukit Lancang path. The two areas have different types of habitat vegetation, which are grass, shrubs, trees and some water sources (BTNBT, 2014). Different vegetation in various habitats is expected to affect the diversity of fauna within it, including species of butterfly (Sulistyani, 2013).

Efforts research on the morphological character of butterflies in the TNBT utilization area has never been done. In addition, studying any type of plant vegetation as a butterfly habitat is also important, because it is can support the life of butterflies species. Peggie (2008) has reported that there are up to 1,600 species of butterflies in Indonesia from 17,500 species of butterflies in the world. However, studies of butterflies in Riau Province still limited, some of them that have been conducted in the Hapanasan area, Rokan Hulu Regency, Riau Province found the number of Nymphalidae families which is dominant because of the abundant feed in the habitat (Chahyadi \& Bibas, 2016). By combining methods of catching and fruit bait, as many as 66 species with 425 individual butterflies in Nymphalidae family were collected (Bassit \& Yulminarti, 2017). Likewise, research conducted in the campus area of Universitas Pasir Pengaraian, Rokan Hulu Regency, Riau Province, found seven families, 16 genera and 24 species of butterflies (Rodianti et al., 2015). Based on these studies, we find out some information and species of butterflies in Riau Province. Thus, it is interesting and important to identify the morphological characteristic and type of habitat vegetation of the Rhopalocera butterfly from different regions in the TNBT utilization zone of Riau Province.

\section{MATERIALS AND METHODS}

There is no information on what types of butterflies exist in the granit waterfall area and the Bukit Lancang path, even though the presence of butterflies in an area is quite important. The study was conducted from February to June 2019. Butterfly samples were taken from the Talang Lakat Resort conservation area, TNBT Utilization Zone in Riau Province. The sampling area was divided into two areas namely Granit waterfall/Air terjun Granit which is located at the latitude of S 00'48'55.4" E 102 31'36.6" and Bukit Lancang Path/Jalur Bukit Lancang which is located at S $00^{\circ} 50^{\prime} 28.6^{\prime \prime} \mathrm{E} 102^{\circ} 30^{\prime} 59.88^{\prime \prime}$ with the distance between both area as far as $1.5 \mathrm{~km}$. The determination sampling areas was based on the condition of the vegetation type and structure that construct each sampling area which represents in the whole area. Sample identification and data analysis were carried out at the Zoology Laboratory of the Faculty of Mathematics and Natural Sciences, Universitas Riau. The procedure in this study was carried out by exploring the sampling area while capturing butterflies using insect nets along the path. Butterflies 


\section{JURNAL BIDDJATI}

http://journal.uinsgd.ac.id/index.php/biodjati

sampling was carried out at 08.00-11.30 a.m and 15.00-17.30 p.m when the sun was bright enough and three observations were made for each region (Sihombing, 2002; Peggie, 2014).

Butterflies that have small size were killed by pressing the thoracic while medium and otherwise large butterflies were killed by injecting 70\% alcohol on the thorax (Arisandi \& Syamsi, 2018). The butterflies were put into papilot envelopes with the right and left wings cupped to prevent damage. If there was a rare type of butterfly then we only took pictures for the identification process (Herlina, 2017), while the butterfly was released again. We took a maximum of three individuals for each species, the number of samples taken was limited it is taken from a conservation area. All specimens were taken under permission of TNBT office with the number of registration of BA.04/BTNBT/TU/03/2019. Likewise for vegetation, leaves, flowers and fruits collection were also carried out from several branches for each plant (Djarwaningsih et al., 2011).

The Butterflies sample obtained were pierced on the thorax with an insect needle and stretched on a stretcher. The prepared butterfly samples were then dried in an oven at $40^{\circ} \mathrm{C}$ for two days or adjusted to the butterflies body size. Dried butterflies were set in an insectarium box and labeled (Herlina,
2017; Peggie, 2014; Septianella et al., 2015). Otherwise plants obtained were preserved and made into a herbarium. The documentation of the insectarium and herbarium was taken and further identified in the laboratory.

The process of identification of butterflies was based on morphological characters on the head, thorax, abdomen, legs and wings. Wings are the most important character for identification in the species level. The observed wing characters including the main colors of the forewings and hindwings, the length of the front and back wings, the width of the front and back wings, the shape of the lower wing edge, the shape of the wing tips, and the length of the wing span (Figure 1). Measurement of butterfly body parts was conducted using calipers and ImageJ application (Rueden et al., 2017), while color characters use Munsell color references. Butterfly identification referreds to literatures of: Borror (1992); Corbet \& Pendlebury (1992); Braby (2004); Triplehorn \& Johnson (2005); Gupta \& Mondal (2005); Abang (2006); Peggie \& Amir (2006); Peggie (2011) and Baskoro et al. (2018). Plant identification was observed based on the morphological characters of leaves, twigs, flowers and fruit, with referred to the literature og Djarwaningsih et al. (2011).

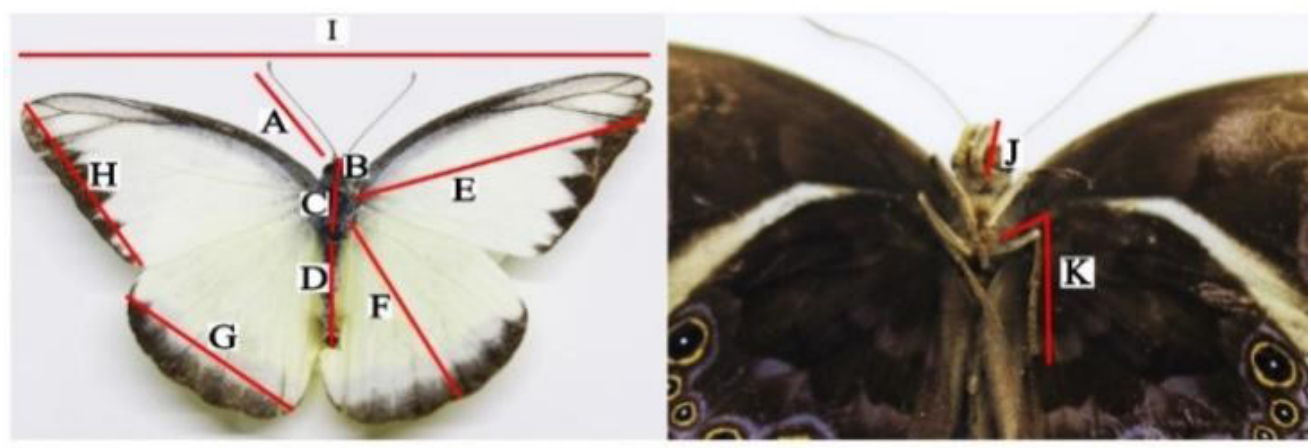

Figure 1. Identification of body character. A: Antenna length, B: Head length, C: Chest length, D: Abdomen length, E: Upper wing length, F: Lower wing length, G: Lower wing width, H: Upper wing width, I: Wing span length, A: Labial pulp length, K: Leg length 


\section{JURNAL BIDDJATI}

http://journal.uinsgd.ac.id/index.php/biodjati

Environmental physical factors mainly influence the existence of butterflies (Priyono \& Abdullah, 2013). In this study temperature, light intensity and humidity were measured. The temperature was measured using a thermometer (Lestari, 2018), the light intensity was measured using a luxmeter (Kamal et al., 2014), while the measurement of air humidity with a hygrometer. Measurement of physical factors was conducted every day at the beginning and end of the observation, (Febrita et al., 2013). The average value of all measurement obtained was presented descriptively in the form of tables and figures.

\section{RESULTS AND DISCUSSION}

\section{Species of Butterflies and Type of Vegeta- tion}

Based on the identification result, we found 27 species of butterflies with a total of 41 individuals. The species consists of six families with the highest number of species found was Nymphalidae (10 species) (Table 1). There were a total of 27 plat species from 18 families observed and identified where 28 species found in the Granit waterfall area and 9 found in Bukit lancang path (Table 2).

Table 1. Number of Rhopalocera individual and species from Granit Waterfall Area (AT) and Bukit Lancang Path (JB)

\begin{tabular}{|c|c|c|c|c|}
\hline \multirow{2}{*}{ Family Name } & \multirow{2}{*}{ Species Name } & \multicolumn{2}{|c|}{ Area Code } & \multirow{2}{*}{ Number of Individua } \\
\hline & & AT & JB & \\
\hline \multirow[t]{2}{*}{ Hesperiidae } & Isma iapis & $\sqrt{ }$ & & 1 \\
\hline & Koruthaialos sindu & $\sqrt{ }$ & & 3 \\
\hline Riodinidae & Zemeros sp. & $\sqrt{ }$ & & 1 \\
\hline \multirow[t]{5}{*}{ Lycaenidae } & Jamides pura & $\sqrt{ }$ & $\sqrt{ }$ & 1 \\
\hline & Jamides parasaturatus & $\sqrt{ }$ & & 1 \\
\hline & Logania malayica & $\sqrt{ }$ & & 1 \\
\hline & Acytolepis puspa & $\sqrt{ }$ & & 1 \\
\hline & Arhopala sp. & $\sqrt{ }$ & & 1 \\
\hline \multirow[t]{10}{*}{ Nymphalidae } & Mycalesis mineus & $\sqrt{ }$ & & 1 \\
\hline & Athyma perius & $\sqrt{ }$ & & 1 \\
\hline & Danaus melanippus & $\sqrt{ }$ & & 3 \\
\hline & Xanthotaenia busiris & $\sqrt{ }$ & & 1 \\
\hline & Junonia atlites & $\sqrt{ }$ & & 3 \\
\hline & Acreae terpsicore & $\sqrt{ }$ & $\sqrt{ }$ & 2 \\
\hline & Pandita sinope & $\sqrt{ }$ & & 2 \\
\hline & Hypolimnas bolina bolina & $\sqrt{ }$ & & 2 \\
\hline & Mycalesis maianeas & $\sqrt{ }$ & & 1 \\
\hline & Mycalesis perseoides & $\sqrt{ }$ & & 1 \\
\hline Papilionidae & Graphium agamemnon & & $\sqrt{ }$ & 1 \\
\hline \multirow[t]{6}{*}{ Pieridae } & Appias lyncida & & $\sqrt{ }$ & 3 \\
\hline & Hebomoia glaucippe & & $\sqrt{ }$ & 1 \\
\hline & Catopsilia pyranthe & $\sqrt{ }$ & & 1 \\
\hline & Eurema hecabe & $\sqrt{ }$ & & 3 \\
\hline & Eurema sari & $\sqrt{ }$ & & 2 \\
\hline & Leptosia nina & $\sqrt{ }$ & & 3 \\
\hline Total & & 22 & 5 & 41 \\
\hline
\end{tabular}




\section{JURNAL BIDDJATI}

http://journal.uinsgd.ac.id/index.php/biodjati

Table 2. Plants family and species of Butterflies habitat vegetation from Granit Waterfall Area (AT) and Bukit Lancang Path (JB)

\begin{tabular}{|c|c|c|c|}
\hline \multirow{2}{*}{ Family } & \multirow{2}{*}{ Species } & \multicolumn{2}{|c|}{ Sampling Area } \\
\hline & & AT & JB \\
\hline \multirow[t]{2}{*}{ Acanthaceae } & Asystasia gangetica & $\sqrt{1}$ & $\sqrt{ }$ \\
\hline & Lindernia anagalis & $\sqrt{ }$ & \\
\hline \multirow{7}{*}{ Asteraceae } & Ageratum conyzoides & $\sqrt{ }$ & \\
\hline & Clibadium surinamensis & $\sqrt{ }$ & $\sqrt{ }$ \\
\hline & Bidens pilosa & $\sqrt{ }$ & \\
\hline & Cyanthillium cinereum & $\sqrt{ }$ & \\
\hline & Synedrella nodiflora & $\sqrt{ }$ & \\
\hline & Mikania micranta & $\sqrt{ }$ & \\
\hline & Chromolaena odorata & $\sqrt{ }$ & \\
\hline Boraginaceae & Heliotropium indicum & $\sqrt{ }$ & \\
\hline \multirow{5}{*}{$\begin{array}{l}\text { Euphorbeaceae } \\
\text { Fabaceae }\end{array}$} & Macaranga gigantea & $\sqrt{ }$ & \\
\hline & Mimosa pudica & $\sqrt{ }$ & \\
\hline & Desmodium heterocarpon & $\sqrt{ }$ & \\
\hline & Crotalaria anagyroides & $\sqrt{ }$ & \\
\hline & Aeschynomene americana & $\sqrt{ }$ & \\
\hline \multirow{3}{*}{$\begin{array}{l}\text { Limnocharitaceae } \\
\text { Malvaceae }\end{array}$} & Limnocharis flava & $\sqrt{ }$ & \\
\hline & Sida rhombifolia & $\sqrt{ }$ & \\
\hline & Urena lobata & & $\sqrt{ }$ \\
\hline \multirow[t]{2}{*}{ Melastomataceae } & Clidemia hirta & $\sqrt{ }$ & $\sqrt{ }$ \\
\hline & Melastoma malabatricum & $\sqrt{ }$ & $\sqrt{ }$ \\
\hline Moraceae & $\begin{array}{l}\text { Ficus auriculata } \\
\text { Ficus ampelas }\end{array}$ & $\sqrt{ }$ & $\sqrt{ }$ \\
\hline Orchidaceae & Arundina graminifolia & $\sqrt{ }$ & \\
\hline \multirow{3}{*}{$\begin{array}{l}\text { Polygalaceae } \\
\text { Rubiaceae }\end{array}$} & Polygala paniculata & $\sqrt{ }$ & \\
\hline & Nauclea orientalis & & $\sqrt{ }$ \\
\hline & Mussaenda frondosa & $\sqrt{ }$ & \\
\hline Verbenaceae & Stachytarpheta jamaicensis & $\sqrt{ }$ & \\
\hline Vitaceae & Sp. 1 & $\sqrt{ }$ & $\sqrt{ }$ \\
\hline Poacea & Paspalum conjugatum & $\sqrt{ }$ & \\
\hline Lamiaceae & Hyptis capitata & $\sqrt{ }$ & \\
\hline Cleomaceae & Cleome rutidosperma & $\sqrt{ }$ & \\
\hline Rutacea & Evodia $\mathrm{sp}$ & & $\sqrt{ }$ \\
\hline Total species & & 28 & 9 \\
\hline Total family & & 18 & 8 \\
\hline
\end{tabular}

The Granit waterfall area has more butterfly species compared to the Bukit Lancang path (Table 1). The butterflies found in the Granit waterfall area consisted of five families namely Nymphalidae, Pieridae, Lycaenidae, Hesperidae and Riodinidae. While in the Bukit Lancang path only four families found, where Hesperidae and Riodinidae were not found in this region. The dominance of Nymphalidae species is due to their higt ability to adapt Jurnal Biodjati 5(1):125-137, May 2020 to the environment and has a variety of food types (polyphagous) (Corbet \& Pendlebury, 1956; Rahayu \& Basukriadi, 2012; Mogan et al., 2018). Therefore the Nymphalidae has the highest number of species in the Rhopalocera suborder (Borror et al., 1992; Lamatoa et al., 2013).

The number of butterflies in the Granit Waterfall region is relatively high, due to the quite diverse of forage vegetation. The plants 


\section{JURNAL BIDDJATI}

http://journal.uinsgd.ac.id/index.php/biodjati

that dominate the Granit Waterfall include families of Asteraceae, Fabaceae, Orchidaceae and Malvaceae (Table 2), some of these plant families are the source of foods butterflies. The high number of butterfly species in an area is influenced by abiotic factors such as temperature, humidity and light intensity (Simanjuntak, 2000). Granit waterfall region has a high light intensity of 16833 Lux, a temperature of $29^{\circ} \mathrm{C}$ and a high humidity of $73.7 \%$. The appropriate environmental factors for optimal butterfly activity are temperatures of $15-45^{\circ} \mathrm{C}$ (Jumar, 2000), humidity ranging from $60 \%-75 \%$ (Kingsolver, 1985 in Ariani, 2013) and light intensity 2000-7500 lux (Nurjanah, 2010). In addition, the availability of water sources and the presence of open space needed by butterflies as a place for sunbathing to warm the body (Sihombing, 2002) in the waterfall area is one of the factors of butterfly diversity.

Unlike the Granit Waterfall, the Bukit Lancang path area, has a smaller number of species, that only five were found (Table 1). This is thought to be due to the lack of host plant that acts as a food source (Table 2) and also the suboptimal environmental conditions. The presence of a species of butterfly in a place is determined by the presence of plants that feed it in the larval phase to adulthood (Corbet \& Pendlebury, 1992; Busnia, 2006; Peggie \& Amir, 2006; Sari et al., 2019). There are only nine species from eight families of plants found in this area, a very small number compare to the ones found in the Granit waterfall area. Plants that butterflies like to eat the most are the family of Aristolochiaceae, Rutaceae, Asteraceae, Lauraceae and Annonaceae (Peggie, 2014). However, in the catchment area of the Bukit Lancang Path, only plants from the Asteraceae and Rutaceae were found (Table 2). A large number of plants of the Asteraceae that belong to seven species founds in the
Granite waterfall area, whereas in the Bukit Lancang path region there was only one species. Asteraceae is a plant that butterflies like to eat because it has many sources of nectar. In addition, most of them have the character of a tubular flower crown, have a bright color and a distinctive aroma because they contain essential oil (Arumnaisha et al., 2014). Moreover, based on the results of the examination of the abiotic conditions, the Bukit Lancang path region has temperatures of $27-28^{\circ} \mathrm{C}$, the humidity of $66-78 \%$ and low light intensity of 1895 Lux. These habitat conditions are less favored by butterflies, such as low light intensity while humidity is too high. Butterflies prefer open spaces or places that have a light canopy cover as the adaptation of butterflies that always need sunlight to sunbathe (Panjaitan, 2011) and work in bright, warm and calm conditions (Peggie \& Amir, 2006). Environmental conditions with high humidity may cause slow growth and development of butterflies (Koh \& Sodhi, 2004).

\section{Morphological Characteristics of Rhopalo- cera Species Antenna Character}

The characters observed arounds the head of the butterfly are antenna shape, head length and color, proboscis and labial pulp. The three forms of antenna observed are rounded end, tapered end and string end (Figure 2). The Hesperiidae and Riodinidae were dominant families that have the shape of a tapered antenna with a far distance between the left and right antennas (Peggie, 2014). This type of antenna found in the species of Zemeros sp. As for the antenna of the Nymphalidae observed vary between species. In addition, the Nymphalidae has a longer antenna compared to other families. The species of Xanthotaenia busiris has the antenna of $20 \mathrm{~mm}$ long. The family with the shortest antenna length was 


\section{JURNAL BIDDJATI}

http://journal.uinsgd.ac.id/index.php/biodjati

Lycaenidae in the species of Acytolepis puscytolepis with the antenna of $2.7 \mathrm{~mm}$. Papilionidae, Hesperiidae, Riodinidae and Pieriidae have antenna lengths that are quite balanced with their body size.

\section{Thorax Character}

The Hesperiidae species generally has a stronger and fatter thorax (chest) shape compared to other families and has a blackish brown color (Peggie, 2014). The observations obtained on thorax characteristics including thorax size and color. Thorax color is dominated by brown, black and yellow (Figure 3). All families almost have brown and black thorax colors except the genus Eurema of the Pieridae family that has a yellow thorax color. Thorax size is also one of the key identifications observed. Chest length size of the Nymphalidae family was larger than that of other families, ranging from 3-9 $\mathrm{mm}$. The smallest chest length was the family Pieridae in the species Leptosia nina.

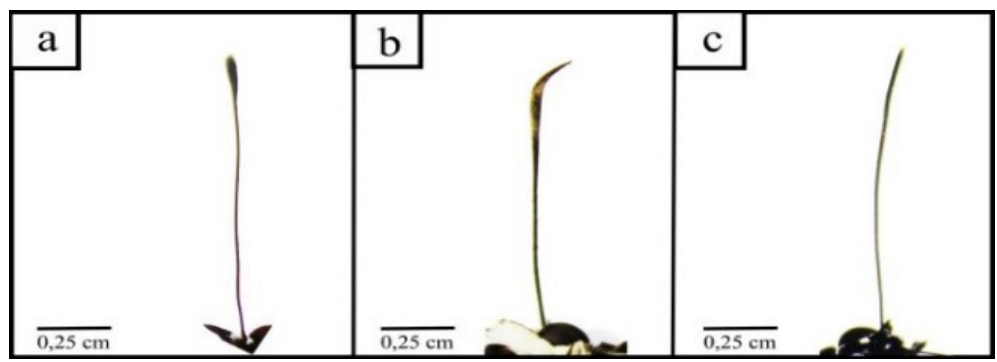

Figure 2. Antenna forms of butterflies. (a) rounded ends (Lycaenidae),

(b) tapered ends (Hesperidae), (c) string ends (Nymphalidae)
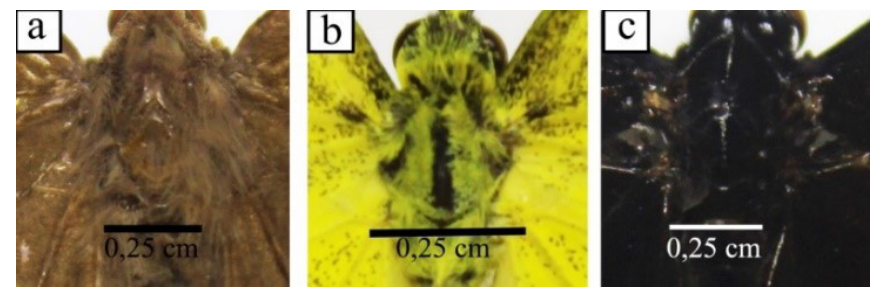

Figure 3. Thorax color of butterflies. a. Brown (Hesperidae), b. Yellow (Pieridae), c. Black (Nymphalidae)

\section{Abdomen Character}

The results showed the difference in color and size of the abdomen of the butterfly. The dominant colors are brown, white, black and yellow (Figure 4). Abdominal sizes range from $\leq 10 \mathrm{~mm}$ and $\geq 10 \mathrm{~mm}$. The abdomen size of the Hesperiidae and Rionidae have the smallest size among all families. Meanwhile, the largest abdomen size found in the type of Nymphalidae

\section{Leg Character}

The legs become one of the key characteristics of identification especially the form of the tibia, tarsus and the presence of spurs on the limbs (Borror et al., 1992). A pair of front limbs is one of the keys to the butterfly family. The Nymphalidae has a pair of front limbs that do not develop so it does not important for walking and there are scales that resemble brushes usually owned by male butterflies. In other types of the family all three limbs develop well (Peggie, 2014). The color of the limbs observed was generally four colors of brown, black, white and yellow (Figure 5). The Hesperiidae and Rionidae families have dominant limb colors, for example, the spe- 


\section{JURNAL BIDDJATI}

http://journal.uinsgd.ac.id/index.php/biodjati

cies I. iapis and Zemeros sp. The Lycaenidae and Papilionidae families are predominantly black limbs. The Nymphalidae has a variety of limb colors, the Pieridae family has dominant white and yellow limb colors (A. lyncida and E. sari).
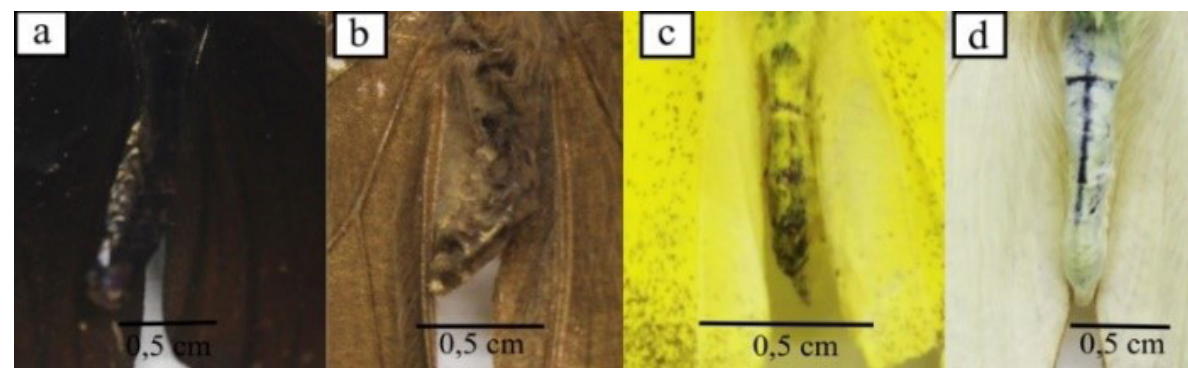

Figure 4. Abdomen color of butterflies. a. Black (Papilionidae), b. Brown (Nymphalidae), c. Yellow (Pieridae), d. white (Hesperidae)

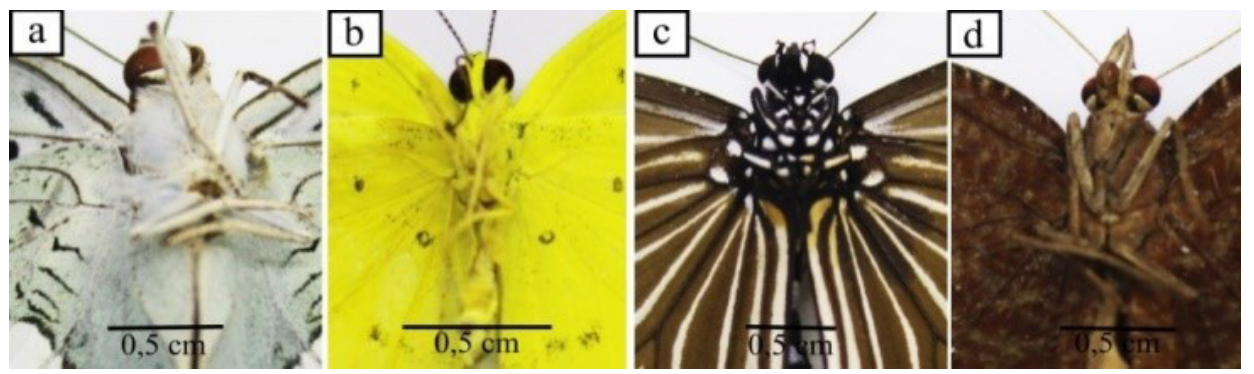

Figure 5. Leg color of butterflies. a. White (Pieridae), b. Yellow (Pieridae), c. Black (Papiolinidae), d. Brown (Hesperidae)

\section{Wings Character}

Variations in wing shape that were successfully observed in this study were the lower wing edges and the upper wing tips. The shape of the lower wing edge consists of three forms, namely the shape of a smooth, wavy edge and an extension like a tail (Figure 6). The Nymphalidae family is more dominant in the form of smooth and bumpy underside edges. The Pieridae family only has a smooth shape of the lower wing edge, such as in the species A. lyncida. The shape of an extension like a tail is owned by the Papilionidea family, dubbed the swallow tail butterfly (Triplehorn \& Johnson, 2005) and also found in the Lycaenidae family. Meanwhile, the Rionidae family has the shape of a smooth lower wing edge, found in the species of Zemeros sp. In addition to variations in the shape of the wing edge, another character observed was the shape of the upper wing tip. There are two forms of wing tips namely rounded and tapered wingtips. The results showed the shape of the rounded wingtip dominates more. The shape of the tapered upper wing was found in the family of Papilionidea, Pieridae, Hesperiidae and Riodinidae. The shape of the rounded upper wing was found in the families Nymphalidae and Lycaenidae. Distinguishing features that become a reference in the characteristics of each species are the color pattern on the wings. The color and pattern of wings are important features to recognize butterfly species. The Papilionidea family has a different color pattern to determine sexual dimorphic between males and females (Peggie, 2014). The results obtained from the Nymphalidae family vary in the variety of color patterns. The Lycaenidae family is dominated by single color patterns (Figure 7). 


\section{JURNAL BIDDJATI}

http://journal.uinsgd.ac.id/index.php/biodjati

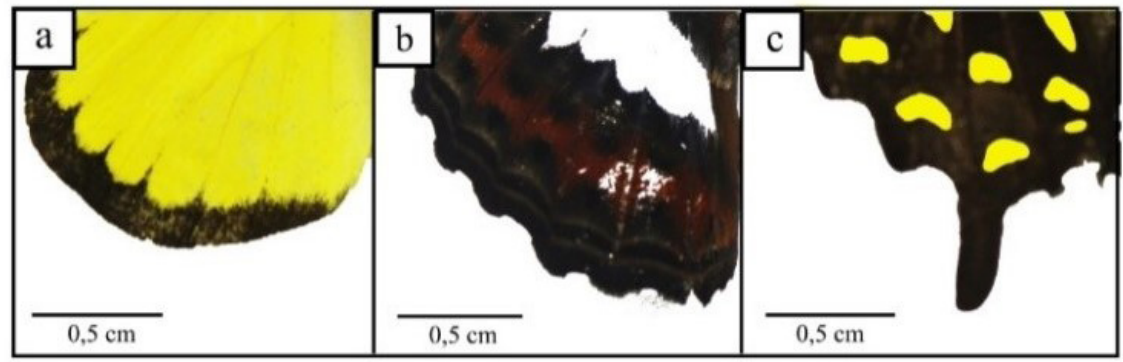

Figure 6. The edge form of butterflies' back wing, (a) smooth (Pieridae), (b) wavy (Nymphalidae), (c) extension tail-like (Papilionidae)

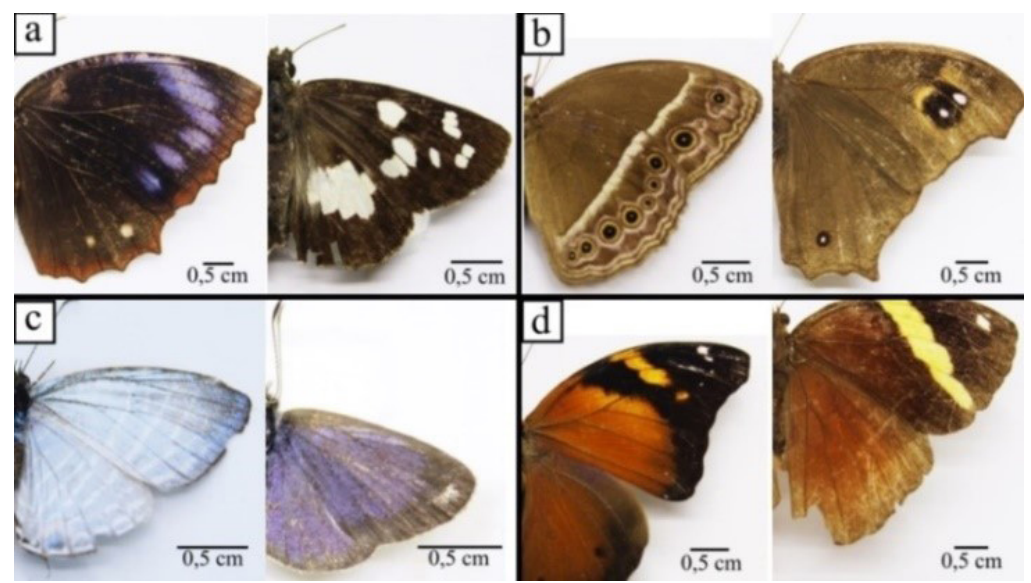

Figure 7. Color pattern on butterflies' wing: a. Spotted (Hesperidae), b. Eyespot (Nymphalidae), c. Plain (Lycaenidae) d. Colour band (Nymphalidae)

\section{Identification Key}

Identification key for the family of Lyaenidae, Pieridae \& Nymphalidae. (Corbet \& pendlebury, (1992); Abang, (2006); Peggie \& Amir, (2006); Peggie (2011); Baskoro et al. (2018).

Lycaenidae

1. a. The color of the antenna is black, the shape of the antenna tip is rounded Arhopala sp.

b. The color of the antenna is black, the shape of the tip of the antenna is tapered Acytolepis puspa

2. a. The color of the upper wing is blue, the color of the lower wing is gray 3

b. The upper wing color is blue, the lower wing color is brown Logania malayica

3. a. The shape of the lower wing edge extension / tail, back wing width $\geq 1 \mathrm{~mm}$... Jamides pura

b. The shape of the lower wing edge extension / tail, back wing width $1 \mathrm{~mm}$ Jamides parasaturatus 


\section{JURNAL BIDDJATI}

http://journal.uinsgd.ac.id/index.php/biodjati

Pieridae

1. a. The shape of the antenna is rounded, the antenna length is $\geq 1 \mathrm{~mm}$ 2

b. The shape of the antenna tip is rounded, the antenna length is $\leq \mathrm{mm}$

2. a. Black upper thorax color, white lower thorax color Appias lyncida

b. Gray upper thorax color, piston bottom color yellow Delias hyparete

3. a. The shape of the upwing is tapered, white color of wing with broad dark colored apex Catopsilia pyranthe

b. The shape of the upwing is rounded, white color of wing with narrow dark colored apex ...

4. a. The color of the hind wing is white, the hindwing length is $\leq 1 \mathrm{~cm}$ Leptosia nina

b. The color of the hind wing is yellow, the hindwing length is $\geq 1 \mathrm{~cm}$ 5

5. a. The color of the lower abdomen is black, the color of the upper abdomen is yellow Eurema hecabe

b. The color of the lower abdomen is black, the color of the upper abdomen is black

Eurema sari

Nympahlidae

1. a. Brown head color, Mycalesis sp.

b. Brown head color, round shape antenna 2

2. a. Antenna length $\leq 1 \mathrm{~cm}$, brown proboscis color Athyma perius

b. The antenna length is $1 \mathrm{~cm}$, black probocis Acreae terpsicore

3. a. The upper thorax color is brown, the upwing color is brown Mycalesis perseoides

b. The upper thorax color is black, the color of the upwing is black ........ Mycalesis maianeas

4. a. Thorax length $\geq 1 \mathrm{~cm}$, black hindwing color Danaus melanippus

b. Thorax length $\geq 1 \mathrm{~cm}$, brown hindwing color Hypolimnas bolina bolina

5. a. The shape of the edge of the corrugated wing Junonia atlites

b. Smooth wing edge shape 6

6. a. The shape of the tip of the upwing is rounded, abdomen length $\leq 1 \mathrm{~cm}$....... Pandita sinope b. The shape of the tip of the upwing is rounded, abdomen length $\geq 1 \mathrm{~cm}$

Xanthotaenia busiris

The number of butterfly species caught in both regions is 27 species with 22 genera and six families. As many as 22 species of butterflies found in the Granite waterfall area, while in the Bukit Lancang Path only consists of five species. This is supported by the presence of vegetation species that serve as habitat and food for butterflies that more commonly found in the granite waterfall area (28 species), than in the Bukit Lancang Path (9 species). Morphological characters that can distinguish between species found in the antenna character consist of three shapes, namely tapered, rounded and stringed. The color character on Ihya et al. thoracic was dominated by black, yellow and brown, while the color on the abdomen and legs was dominated by black, brown, yellow and white. The key character at the species level is the shape of the color pattern on the wings, ie spots, eye spots, plain colors and, color bands and the forms of hindwings that is smooth, wavy or tailed. Then the shape of the tip of the hindwing is tapered and curved. Based on the conditions of temperature, rainfall, and humidity, the granite waterfall area was more supportive of butterfly life, than those in Bukit Lancang Path. 


\section{JURNAL BIDDJATI}

http://journal.uinsgd.ac.id/index.php/biodjati

\section{ACKNOWLEDGEMENTS}

We thank you for the given research grant of the University of Riau LPPM Young Lecturer in 2019. Then also for all parties involved in TNBT Riau Province so that this research can be completed on time.

\section{REFERENCES}

Abang, F. (2006). Butterflies of Malaysia Borneo. Sarawak: Lee Ming Press.

Ariani, L. Putu A. \& Liwa, I. H. M. (2013). Keanekaragaman dan Distribusi Jenis Kupu-Kupu (Lepidoptera) di Kawasan Hutan Taman Wisata Alam Suranadi Sebagai Media Pembelajaran Biologi. Mataram: Fakultas Keguruan dan Ilmu Pendidikan Universitas Mataram.

Arisandi, R. \& Syamsi, F. (2018). Keanekaragaman Jenis Kupu-kupu (Lepidoptera) di Taman Wisata Alam Muka Kuning Batam. SIMBIOSA, 7(1), 64-72.

Baskoro, K., Nanang, K. \& Frendi, I. (2018). Lepidoptera Semarang Raya. Semarang: Departemen Biologi Universitas Semarang.

Bassit, O. R. \& Yulminarti. (2017). Keanekaragaman Kupu-kupu (Lepidoptera: SF, Papilionoidea dan Hesperinoidea) di Kawasan Desa Siabu, Kampar, Riau. Jurnal Riau Biologia, 2(1), 14-18.

Borror, D. J., Triplehorn, C. A. \& Johnson, N. F. (1992). Pengenalan Pelajaran Serangga. dalam; Partosoedjono S, Brotowidjoyo, M. D: Terjemahan dari: Ori an Introduction to the Study of Insects. Yogyakarta: Gadjah Mada University Press.

Braby, M. F. (2004). The Complete Field Guide to Butterflies of Australia. Canberra: CSIRO Publishing.

Balai Taman Nasional Bukit Tigapuluh (BT-
NBP). (2014). Rencana Pengelolaan Jangka Panjang Taman Nasional Bukit Tiga Puluh Periode 2015-2024. Pematang Rebah, Riau.

Busnia, M. (2006). Entomologi. Padang: Andalas University Press.

Campbel, N. A., Reece, J. B. \& Mitchell, L. G. (2000). Biologi. Jakarta: Erlangga.

Chahyadi, E. \& Bibas, E. (2016). Jenis-Jenis Kupu-Kupu (Sub Ordo Rhopalocera) yang Terdapat di Kawasan Hapanasan, Kabupaten Rokan Hulu, Provinsi Riau. Jurnal Riau Biologia, 1(8), 50-56.

Corbet, A. S. \& Pendlebury. (1992). The Butterflies of The Malay Peninsula. Efdinburg and London: Oliver Boyd.

Djarwaningsih, T., Supriatna, A. M. \& Amir. (2011). Flora Cagar Alam Gunung Tukung Gede Serang. Banten: LIPI Press.

Febrita, E., Yustina \& Dahmania. (2013). Keanekaragaman Jenis Kupu-Kupu (Sub ordo Rhopalocera) di Kawasan Wisata Hapanasan Rokan Hulu sebagai Sumber Belajar pada Konsep Keanekaragaman Hayati. Jurnal Biogenesis, 10(2), 48-58.

Gupta, I. J. \& MondaI, D. K. (2005). Red Data Book (Part 2) Butterflies of India. Kolkata: Zoological Survey of India.

Herlina, S. (2017). Kelimpahan Kupu-Kupu Nymphalidae di Kawasan Air Terjun Parangloe Kabupaten Gowa. Skripsi. Makasar: Fakultas Sains dan Teknologi, UIN Alauddin Makassar.

Jumar. (2000). Entomologi Pertanian. Jakarta: Penerbit Rineka Cipta.

Kamal, S., Hasanuddin \& Wardani, H. (2014). Keanekaragaman Rhopalocera Di Pegunungan Mata Ie Kecamatan Darul Imarah Kabupaten Aceh Besar. Jurnal Biotik, 2(2), 77-137.

Koh, K. P. \& Sodhi, N. S. (2004). Importance 


\section{JURNAL BIDDJATI}

http://journal.uinsgd.ac.id/index.php/biodjati

of Reverse, Fragments and Parks for Butterfly Conservation in a Tropical Urban Lanscape. Ecological Applications, 14(6), 1695-1708.

Lamatoa, D. C., Roni, K., Ratna, S. \& Maabuat, P. V. (2013). Populasi Kupu-kupu (Lepidoptera) di Pulau Mantehage Sulawesi Utara. Jurnal Ilmiah Sainsra, 13(1), 52-56.

Lestari, V. C., Erawan, T., Melanie, M. \& Kasmara, H. (2018). Keanekaragaman Jenis Kupu-kupu Familia Nymphalidae dan Pieridae di Kawasan Cirengganis dan Padang Rumput Cikamal Cagar Alam Pananjung Pangandaran. Jurnal Agrikultura, 29(1), 1-8.

Mogan, Y., Koneri, R. \& Baideng, E. L. (2018). Keanekaragaman Kupu-kupu (Lepidoptera) di Kampus Universitas Sam Ratulangi, Manado. Jurnal Bioslogos, 8(2), 60-67.

Nurjanah, S. T. (2010). Biologi Troides helena helena dan Troides helena hephaestus (Papilionidae) di Penangkaran. Tesis. Bogor: Institut Pertanian Bogor.

Panjaitan, R. (2011). Komunitas Kupu-kupu Superfamili Papilionoidea (Lepidoptera) di Kawasan Hutan Wisata Alam Gunung Meja, Manokwari, Papua Barat. Thesis. Bogor: Intitute Pertanian Bogor.

Peggie, D. \& Amir, M. (2006). Panduan Praktis Kupu-Kupu di Kebun Raya Bogor. Cibinong: Pusat Penelitian Biologi-LIPI.

Peggie, D. (2008). Kupu-kupu, Keunikan Tiada Tara. Retrieved from https://nasional.kompas.com/ $\mathrm{read} / 2008 / 07 / 21 / 09425169 /$ Sains-Biologi.

Peggie, D. (2011). Кири-Кири Indonesia yang Bernilai dan Dilindungi. Jakarta: PT. Binamitra Megawarna.
Peggie, D. (2014). Mengenal Kupu-Kupu. Jakarta: Pandu Aksara Publishing.

Priyono, B. \& Abdullah, M. (2013). Keanekaragaman Jenis Kupu-Kupu di Taman Kehati Unnes. Biosaintifika, 5(2), 100105.

Putri, R. E. \& Mutiara, D. (2014). Keanekaragaman Kupu-Kupu di Kecamatan Sukarame Kota Palembang Provinsi Sumatera Selatan. Sainmatika, 11(2), 38-42.

Rahayu, S. E. \& Basukriadi, A. (2012). Kelimpahan dan Keanekaragaman Spesies Kupu-Kupu (Lepidotera: Rhopalocera) Pada Berbagai Tipe Habitat di Hutan Kota Muhammad Sabki Kota Jambi. Biospecies, 5(2), 40-48.

Raja, R. N. L. (2012). Studi Keanekaragaman Kupu-kupu yang terdapat di Kawasan Hutan Aek Nauli Kabupaten Simalungun Sumatera Utara. Skripsi. Medan : Jurusan Biologi Fakultas Matematika dan Ilmu Pengetahuan Alam, Universitas Negeri Medan.

Rinanda, A., Farah, D. \& Wahdina. (2016). Studi Keanekaragaman Jenis Kupu-Kupu di DAS Mendalam Taman Nasional Betung Kerihun Danau Sentarum Kabupaten Kapuas Hulu Provinsi Kalimantan Barat. Jurnal Hutan Lestari, 4(4), 437-445.

Rodianti, M., Yolanda, R. \& Mubarak, J. (2015). Kupu-Kupu (Rhopalocera) di Sekitar Kampus Universitas Pasir Pengaraian Kabupaten Rokan Hulu Provinsi Riau. Jurnal Mahasiswa Prodi Biologi UPP, 1(1), 1-2.

Rueden, C. T., Schindelin, J., Hiner, M. C., DeZonia, B. E., Walter, A. E., Arena, E. T. \& Eliceiri, K. W. (2017). ImageJ2: ImageJ for the Next Generation of Scientific Image Data. BMC Bioinformatics. 


\section{JURNAL BIDDJATI}

http://journal.uinsgd.ac.id/index.php/biodjati

Sari, R. P. Mawarni, E. D., Nurlatifah, A., U1innuha, R., Sari, A. K. A., Fitri, A. R., Rachman, R. A., Affandi, M., Rosmanida, Fauziyah, S. \& Irawanto, R. (2019). Keanekaragaman Kupu-Kupu (Insect: Lepidoptera) di Kebun Raya Purwodadi, Pasuruan, Jawa Timur, Indonesia. Prosiding Seminar Nsional Masyarakat Biodiversitas Indonesia, 5(2), 172-178.

Septianella, G., Rosnaeni., Baskoro, Y., Nisrina, L., Qayyimah, D., Aulunia, R., Elfidasari, D. \& Lupiyaningdiyah, P. (2015). Identifikasi Serangga di Kawasan Industri Pertambangan Kapur Palimanan, Cirebon, Jawa Barat. Prosiding Seminar Nsional Masyarakat Biodiversitas Indonesia, 1(8), 1790-1794.

Sihombing, D. T. H. (2002). Satwa Harapan I: Pengantar Ilmu dan Teknologi Budidaya. Bogor: Pustaka Wirausaha Muda.

Simanjuntak, O. F. M. (2000). Kajian Produksi dan Tingkah Laku Beberapa Jenis Kupu-Kupu yang Terdapat di Beberapa Daerah di Kabupaten Bogor. Tesis. Bogor: Institut Pertanian Bogor.
Subahar, T. S. \& Yuliana, A. (2012). Butterfly Diversity as a Data Base for the Development Plan of Butterfly Garden at Bosscha Observatory, Lembang, West Java. Biodiversitas, 11(1), 24-28.

Sulistyani, T. H. (2013). Keanekaragaman Jenis Kupu-Kupu (Lepidoptera: Rhopalocera) di Kawasan Cagar Alam Ulolanang Kecubung Kabupaten Batang. Skripsi. Semarang: Jurusan Biologi FMIPA UNS.

Triplehorn, C. A. \& Johnson, N. F. (2005). Borror and Delongs Introduction to The Study of Insect 7th Edition. United States of America: Thomson Brooks/ Cole. 